\title{
Recombinant Chemokine
}

National Cancer Institute

\section{Source}

National Cancer Institute. Recombinant Chemokine. NCI Thesaurus. Code C1593.

Formulated therapeutic analogs of one of a number of endogenous small polypeptide cytokines with potential antineoplastic activity. Synthesized by macrophages, endothelial cells, keratinocytes, fibroblasts, and smooth muscle cells, chemokines are released in the presence of infection or physical tissue damage, and act as chemoattractants to recruit macrophages, neutrophils, and T cells from the blood to sites of infection or damage. These agents may regulate tumor growth by modulating tumor-associated angiogenesis and metastasis and can either promote or retard tumor growth. (NCl04) 